\title{
Want to Build Students' Civic Engagement? Teach Them How to Use Social Media
}

\author{
JENNIE SWEET-CUSHMAN | CHATHAM UNIVERSITY
}

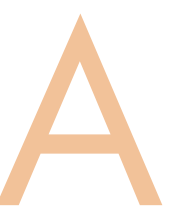

$s$ political information and civic engagement levels have deteriorated, social media has been touted as a potential solution to the decline of both. However, I doubt anyone would argue this positive influence is what we are witnessing on social media. My own research (2019) suggests the failure of social media to capitalize on its promise of greater civic engagement may lie in its concurrent failure to capitalize on its promise of enhanced political information. Political science, as a discipline, with its commitment to enhancing civic engagement, should consider training students to use social media more effectively as a not-insignificant part of this responsibility.

Undergraduate education in other fields may wish to encourage civic engagement but fail to offer training in the realm of politics and citizenship.

This leaves this essential component of civic engage-

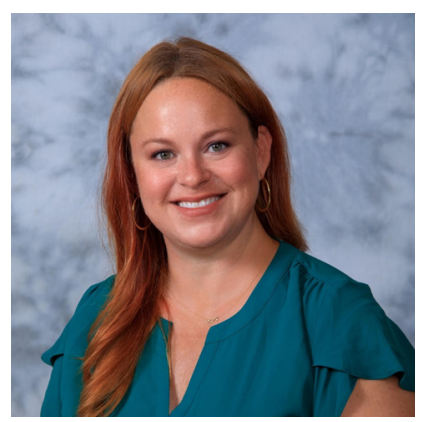

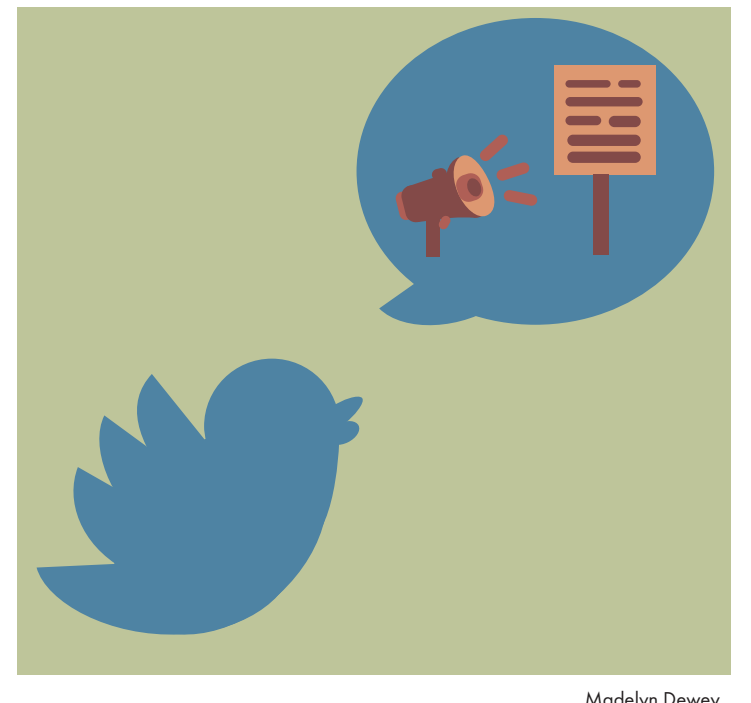

Madelyn Dewey
(2017) find online political engagement and knowledge are higher among students who used Twitter in their political science classes than those who did not. But "real-world" civic engagement is harder to come by. Caliendo et al. (2016) find Twitter use in political science courses did not affect efficacy, political interest, and civic engagement. However, consider the following quote from one of my students, a sophomore education major, in a recent Introduction to American Government course:

"Before having class on Twitter, I had no idea that there was even an impeachment inquiry against President Trump. I do not watch the news, or follow any political figures on social media. The only political news I get is from Buzzfeed-which is very left-and my father on the off-chance that we actually engage in conversation about it. Politics is not something I have ever really been comfortable sitting down and talking about, which is why I usually stray away."

The student is acknowledging a disconnection between ment to political scientists, many of whom seek ways to deepen their ability to foster civic engagement (Thomas and Brower 2017; Matto et al. 2017). Some, like myself, have turned to Twitter as a resource for making this connection between information and action.

Woodall and Lennon

Jennie Sweet-Cushman is associate professor of political science at Chatham University, where she also served as the assistant director of the Pennsylvania Center for Women and Politics from 2013-2019. A former congressional campaign manager herself, Jennie's research focuses on women's political ambition and representation in the US, as well as gender equity in academia. She currently serves as an appointed official on Pittsburgh, Pennsylvania's Equal Opportunity Review Commission. her ability to find and understand good information about politics and her willingness to engage. This may be the missing link: students are not taught the social media literacy they need to draw on for meaningful civic engagement.

The student offered this confession in a reflection she wrote following an exercise I do in the course called "Class on Twitter" (COT).

Each semester for the last five years, I have hosted a synchronous class session on Twitter-where I prompt students to use the platform to learn about an issue of US government or policy. In previous years, we have covered issues ranging from the federal budget to health care reform. This year, the news that Congressional Democrats were launching an impeachment inquiry into President Donald Trump broke the day before COT was scheduled. The topic we would discuss was essentially chosen for us. It was remarkable how many students had little to no understanding of the impeachment process and some, like the student quoted above, were so insulated from political news they 
didn't even know it was happening.

I do this exercise on Twitter because, as the quote from my student exemplifies, approaching 90 percent of young adults (18-29) report actively using social media, but looking for news and information is hardly the primary motivation (Smith and Anderson, 2018; American Press Institute, 2015). However, I maintain it is possible that college students would use social media to learn about politics and government if they had an opportunity to experience how to do so constructively. Students have been mostly allowed to learn how to structure their use of social media on their own and, in doing so, made assumptions about how effective social media is (or can be) as a place to learn about their political environment. In surveying students, they know an echo chamber is one problematic way of curating their social media, but most $(89.1 \%)$ felt they were at least somewhat comfortable discerning diverse viewpoints, but this confidence was less pronounced around their ability to discern trustworthy or objective sources (39.4 and 33.3 percent, respectively). They avoid using it to learn about their political environment; only 18 percent believe social media is a good resource for news (Sweet-Cushman 2019).

\title{
66
}

\author{
Compelling students to learn how to best use social media through meaningful \\ experience and modeling offers a promising way to foster social media literacy \\ and, ultimately, prepare them for engagement as citizens.
}

I see evidence that COT helps with social media literacy, particularly for those students who reported being social media users prior to the exercise (non-users kept an open mind but were unconvinced of the value post-exercise). Following COT, these students reported feeling both more positive about and interested in learning about political issues on social media. Furthermore, they nearly universally left the exercise having expanded their knowledge base, with a new perspective, and having enjoyed a novel way of doing so.

Of course, I do not mean to discount the unfortunate reality that social media is still a major source of misinformation and this poses an increasing threat to the ability to be properly informed and trust sources of information gathered through social media. At the same time, these platforms are also increasingly the primary source for correcting their own inaccuracies (Bode and Vraga 2015). Responsible pedagogy must address this concern. Compelling students to learn how to best use social media through meaningful experience and modeling offers a promising way to foster social media literacy and, ultimately, prepare them for engagement as citizens. As this junior criminology major wrote following our discussion:

"I am a person who tends to just avoid politics for the most part. If I see something that interests me, then I will click in and read it just to be in the general know. Other than that I avoid it.... Overall, this class on Twitter session taught me a lot about how to more effectively use Twitter as a positive source of information and how to find reliable information."

American Press Institute. 2015. "How Millennials Use and Control Social Media." https://www.americanpressinstitute.org/publications/reports/survey-research/millennials-social-media.

Bode, L., \& Vraga, E. K. 2015. "In related news, that was wrong: The correction of misinformation through related stories functionality in social media." Journal of Communication, 65(4), 619-638.

Caliendo, S. M., Chod, S., \& Muck, W. 2016. "Using Twitter to increase political interest in undergraduate students." Journal of Political Science Education, 12(3), 282-301.

Matto, E. C., McCartney, A.R. M., Bennion, E. A. \& Simpson, D. W. eds. 2017. "Teaching Civic Engagement Across the Disciplines." Washington, DC: American Political Science Association.

Smith, A, \& Anderson, M. 2018. "Social Media Use in 2018." Pew Research Center. https://www.pewresearch.org/internet/2018/03/01/social-media-use-in-2018/.

Sweet-Cushman, J. 2019. "Social Media Learning as a Pedagogical Tool: Twitter and Engagement in Civic Dialogue and Public Policy." PS: Political Science \& Politics, 52(4), 763-770.

Thomas, N., \& Brower, N. 2017. "Politics 365: Fostering campus climates for student political learning and engagement." Teaching Civic Engagement Across the Disciplines: 361.

Woodall, G.S., \& Lennon, T. M. 2017. "Using Twitter to Promote Classroom and Civic Engagement." Teaching Civic Engagement Across the Disciplines: 135. 